\title{
Scientific creativity: A bibliometric review and analysis
}

\author{
Surya Haryandi ${ }^{1,}$, , Suyidno Suyidno ${ }^{1, b} *$, Misbah Misbah ${ }^{1, ~ c}$, Dewi Dewantara ${ }^{1, d}$, \\ Saiyidah Mahtari ${ }^{1, e}$, Mohd Ali Ibrahim 2, f \\ ${ }^{1}$ Universitas Lambung Mangkurat. Jl. Hasan Basri Banjarmasin, 70123, Indonesia \\ ${ }^{2}$ Universiti Teknologi Malaysia. 81310 Johor Bahru, Johor, Malaysia \\ a surya.haryandi@ulm.ac.id, ${ }^{b}$ suyidno_pfis@ulm.ac.id, c misbah_pfis@ulm.ac.id, \\ d dewantara_pfis@ulm.ac.id, e saiyidah_pfis@ulm.ac.id, ${ }^{f}$ p-mali@utm.my \\ * Corresponding Author.
}

Received: 28 October 2020; Revised: 30 December 2020; Accepted: 9 January 2021

\begin{abstract}
Scientific creativity is one of the higher-order thinking skills which are highly functional for each individual. Scientific creativity encourages the individual to not only generate creative ideas, but also promotes the notion of the appropriate technology. This article provides an in-depth explanation of the bibliometric analysis of scientific literature in education. The articles search was performed by utilizing Publish or Perish (PoP) software on the Crossref database. The search and sort results discovered that 28 of 200 articles were found between the years of 2019-2020. The selected metadata was edited using Mendeley Desktop software. The edited results were then analyzed further and visualized using the VOSviewer software. Overall, articles with the keyword scientific creativity published in the 2019-2020 period have not been cited, and it is essential to be studied collaboratively not only between national institutions but also internationally. Keywords: Bibliometric Analysis; Creative Thinking; Scientific Creativity
\end{abstract}

How to Cite: Haryandi, S., Suyidno, S., Misbah, M., Dewantara, D., Mahtari, S., \& Ibrahim, M. A. (2021). Scientific creativity: A bibliometric review and analysis. Momentum: Physics Education Journal, 5(1), 10-20. https://doi.org/10.21067/mpej.v5i1.5002

\section{Introduction}

Creativity is not only required by artists and scientists, but also every single individual, in which creativity is essential in solving daily life problems, for instance problems related to professional work (Lau, 2011). Creativity in science is not merely related to an individual's talent. An individual who acquires talent in arts, such as writing poetry or drawing may not be creative in science (Yang et al., 2019). According to psychologists, when someone practices creativity at work, they will feel contented (Lau, 2011). In addition to enhancing personal capacity, creativity also pushes individual to be active and creative to contribute to the surrounding environment (Zainudin \& Irhadtanto, 2016).

Creativity is not merely creating a novel product or idea, but combining several existing products or ideas into one single new idea or product (Komarudin, 2018; Samsudin et al., 2018; Zainudin \& Irhadtanto, 2016). An individual with creative thinking skills can easily innovate and have different perspectives when observing certain object (Akcanca \& Ozsevgec, 2018). Several efforts are able to encourage an individual to promote creative thinking skills, one of which is through education (Patmalasari et al., 2017). In the context of education, high-level cognitive learning outcomes are closely related to students' scientific creativity. This is due to the fact that students with scientific creativity skills above average have a greater curiosity to research than students with scientific creativity below average (Ramadhani \& Sirait, 2015). Scientific creativity requires the development of cognitive skills which students can acquire by studying concepts, theories and natural laws in science (Ozdemir \& Dikici, 2016; Samsudin et al., 2018). Science learning that applies scientific collaboration plays a critical role in the efforts done to increase students' scientific creativity (Astutik \& Prahani, 
2018) Scientific creativity continues to improve and develop into a learning model, which in inquiry is called a learning model for the creative process of inquiry (Wahyudi et al., 2019).

When students conduct research, it help stimulate their sense of creativity thinking, which is associated with science process skills (Ozdemir \& Dikici, 2016). Based on the results of the Structured Equation Modeling (SEM) analysis, it was discovered that there was a mutually supportive influence between the learning environment of creativity and the achievement of science learning outcomes on students' inquiry abilities and scientific creativity (Yang et al., 2019). Structured science learning can increase students' scientific creativity, which, if it continues to develop, can produce the appropriate products (Akcanca \& Ozsevgec, 2018). In order to enhance students' scientific creativity, the role, guidance and awareness of teachers in incorporating creativity in the classroom is exceptionally demanded (Akcanca \& Ozsevgec, 2018; Astutik \& Prahani, 2018).

Scientific creativity has often been discussed and examined in several research (Astutik \& Prahani, 2018; Suyidno et al., 2019, 2016). Based on the results according to Google Scholar and Crossref databases, during 2019-2020, there were several bibliometric analysis articles on creativity, specifically in the context of education (Hernández-Torrano \& Ibrayeva, 2020), in the context of urban-planning (Rodrigues \& Franco, 2020), and in the context of business (Rosa et al., 2019). Bibliometric analysis studies in the education context were carried out to describe the collaborative relationship patterns of researchers from the United States and other English-speaking countries, European countries, and several other Asian countries (Hernández-Torrano \& Ibrayeva, 2020). However, there is no discovery of any patterns of collaboration between researchers from Indonesia and researchers from abroad who have studied scientific creativity in the context of education. In addition, based on data compiled from the Google Scholar and Crossref databases, no research of a bibliometric analysis of scientific creativity in the education context in Indonesia has been found for the last 10 years.

Referring to the aforementioned reasons, this article intends to provide a comprehensive explanation through bibliometric literature analysis on scientific creativity in education. Literature obtained from the Crossref database was then analyzed and categorized based on the author's affiliation and distribution. Through this analysis, the topics of 'scientific creativity' which are often published and the opportunities for future research were investigated. The methodology used was bibliometric analysis by using Publish or Perish (PoP) software. The results obtained through PoP were then imported into the Mendeley Desktop software for editing, and the distribution patterns were visualized using the VOSviewer software. Then, the research was continued by discussing the findings and drawing conclusions based on the bibliometric literature analysis carried out. Bibliometric analysis was taken to identify the publication of articles that examine the topic of scientific creativity in the 2019-2020 period. Not only that, through bibliometric analysis, it is expected that it can reveal the collaboration patterns of writers between institutions on the topic of scientific creativity.

\section{Method}

A review of the bibliometric literature in this article was based on a systematic and explicit method (Garza-Reyes, 2015). The research method used in bibliometric analysis adopted the fivestage method (Setyaningsih et al., 2018) which can be seen in Figure 1.

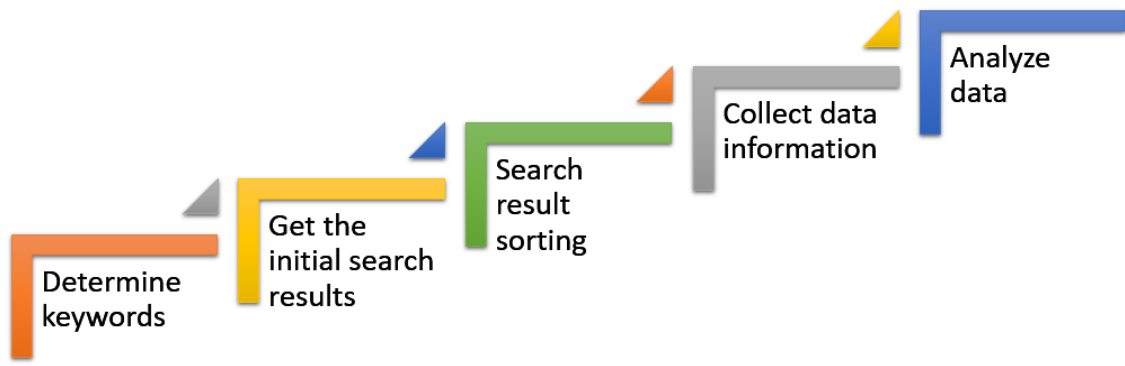

Figure 1. Five Stages of Bibliometric Analysis Method 


\section{Finding Keywords}

The literature search began on August 2019, with the keyword "scientific creativity". The Crossref database was chosen as it is a large, reputable non-profit organization, which associated with thousands of publishers and had hundreds of millions of metadata for journal articles, books, etc. PoP was selected as it is proven to be the most effective software in assisting article metadata tracking (Baneyx, 2008).

\section{Obtaining Initial Search Results}

The search results were focused specifically on articles published during 2019-2020. Initially, 200 articles were obtained from the Crossref database. The results of these searches were stored in Research Information Systems (RIS) format in PoP.

\section{Sorting Search Results}

The articles were then sorted based on their publication forms, precisely in the form of journal articles, which consisted of 144 articles. There were 144 articles found by PoP tracing results with 0 citations ( 0.00 citation/year). The 144 articles were further classified based on their fields, specifically science, and based on the realm of education, specifically secondary education and higher education, which at the end only consisted of 28 articles. The sorting results were saved in RIS format. The RIS formatted data were then imported into the Mendeley Desktop software for further data analysis.

\section{Collecting Information Data}

In Mendeley Desktop software, the RIS formatted data was reviewed by checking the metadata individually. If there was incomplete metadata, then it must be edited in order to match the metadata with the published article. Editing results were also saved in the format of RIS.

\section{Analyzing Data}

The RIS formatted data, as edited by Mendeley Desktop, underwent further analysis through the use of the VOSviewer software. VOSviewer can analyze data efficiently and produce analysis output in the form of very interesting visualizations and comprehensive information (van Eck \& Waltman, 2010).

\section{Results and Discussion}

\section{Publication and Citation Structures}

The output documents of the PoP software were analyzed by using VOSviewer software to determine the most frequently used search keywords. The search keywords used in VOSviewer were specifically utilized for data collection and analysis purposes. VOSviewer served as a visualization medium of a map from the bibliometrics.

In the beginning, 200 articles were obtained from the Crossref database. The articles were then sorted based on their publication forms, specifically in the form of journal articles, which consisted of 144 articles. This data was collected from 2019 to 2020 with the keyword 'scientific creativity' in Indonesian. As shown by PoP, there were 144 articles indicated with tracing results of 0 citations ( 0.00 citation/year). The 144 articles were then further sorted based on their field, which was related to science, and based on the context of education, specifically secondary education and higher education. In the end, 28 articles were collected. Based on the final sorting results, 0 citations ( 0.00 citation/year) were obtained. The results of the comparison between the metric data output from the first sorting and the second sorting can be seen in Table 1.

Referring to the data displayed by PoP, the articles were systematically sorted from those with the highest relevance to the keywords to those with the lowest relevance, as can be examined in Table 2. 
Momentum: Physics Education Journal, 5 (1), 2021, 13

Surya Haryandi et al

Table 1. Comparison between PoP Metric Data Output

\begin{tabular}{lll}
\hline Metric Data & First Sorting & Second Sorting \\
\hline Keyword & 'scientific creativity' & 'scientific creativity' \\
Year of publication & $2019-2020$ & $2019-2020$ \\
Number of articles & 144 & 28 \\
Citation & 0 & 0 \\
Citation/year & 0,00 & 0,00 \\
Citation/article & 0,00 & 0,00 \\
Author/article & 1,83 & 2 \\
h_index & 0 & 0 \\
g_index & 0 & 0 \\
hl_normal & 0 & 0 \\
hl_yearly & 0,00 & 0,00 \\
\hline
\end{tabular}

Table 2. Top 10 Articles with the Highest Relevance by PoP

\begin{tabular}{|c|c|c|c|c|c|c|}
\hline No. & $\begin{array}{c}\text { Year of } \\
\text { Publication }\end{array}$ & Author & Title & Journal & Citation & Publisher \\
\hline 1. & 2019 & $\begin{array}{l}\text { Maria Dea } \\
\text { Pramudita, Kadwi } \\
\text { Mentari, Monica } \\
\text { Flaviyana }\end{array}$ & $\begin{array}{l}\text { The effectiveness of } \\
\text { using rhyme-heuristic } \\
\text { model questions in } \\
\text { students' mathe- } \\
\text { matical creativity }\end{array}$ & $\begin{array}{l}\text { ANARGYA: } \\
\text { Mathematics } \\
\text { Education } \\
\text { Scientific } \\
\text { Journal }\end{array}$ & 0 & $\begin{array}{l}\text { Maria Kudus } \\
\text { University }\end{array}$ \\
\hline 2. & 2019 & Muh. Bachtiar & $\begin{array}{l}\text { The effect of learning } \\
\text { strategies on cogni- } \\
\text { tive abilities and } \\
\text { creativity in solving } \\
\text { mathematical } \\
\text { problems }\end{array}$ & $\begin{array}{l}\text { Adaara: Journal } \\
\text { of Islamic } \\
\text { Education } \\
\text { Management }\end{array}$ & 0 & $\begin{array}{l}\text { Bone State } \\
\text { Islamic Institute }\end{array}$ \\
\hline 3. & 2019 & Masiah Masiah & $\begin{array}{l}\text { Implementation of } \\
\text { inquiry-oriented bio- } \\
\text { logy learning media } \\
\text { to increase students' } \\
\text { creativity }\end{array}$ & $\begin{array}{l}\text { Bioscientist: } \\
\text { Journal Article } \\
\text { of Biology }\end{array}$ & 0 & $\begin{array}{l}\text { LPPM IKIP } \\
\text { Mataram }\end{array}$ \\
\hline 4. & 2020 & $\begin{array}{l}\text { Muhammad } \\
\text { Arifuddin, Mustika } \\
\text { Wati, Sarah Miriam, } \\
\text { Suyidno Suyidno, } \\
\text { Misbah Misbah, } \\
\text { Saiyidah Mahtari, M } \\
\text { Deni, Muhammad } \\
\text { Hafiz Ridho }\end{array}$ & $\begin{array}{l}\text { Development of } \\
\text { students' worksheet } \\
\text { designs based on } \\
\text { scientific creativity } \\
\text { for science-physics } \\
\text { teachers in South } \\
\text { Kalimantan }\end{array}$ & $\begin{array}{l}\text { Bubungan } \\
\text { Tinggi: Journal } \\
\text { of Community } \\
\text { Service }\end{array}$ & 0 & $\begin{array}{l}\text { Center for } \\
\text { Journal } \\
\text { Management } \\
\text { and Publication, } \\
\text { Lambung } \\
\text { Mangkurat } \\
\text { University }\end{array}$ \\
\hline 5. & 2019 & Andi Mustika Abidin & $\begin{array}{l}\text { Teachers' creativity } \\
\text { in using learning } \\
\text { models to enhance } \\
\text { student learning } \\
\text { outcomes }\end{array}$ & DIDAKTIKA & 0 & $\begin{array}{l}\text { Bone State } \\
\text { Islamic Institute }\end{array}$ \\
\hline 6. & 2020 & $\begin{array}{l}\text { Wanda Nugroho } \\
\text { Yanuarto }\end{array}$ & $\begin{array}{l}\text { Increasing creativity } \\
\text { in mathematics } \\
\text { through problem } \\
\text { solving learning } \\
\text { method }\end{array}$ & $\begin{array}{l}\text { De Fermat: } \\
\text { Mathematics } \\
\text { Education } \\
\text { Journal }\end{array}$ & 0 & $\begin{array}{l}\text { Balikpapan } \\
\text { University }\end{array}$ \\
\hline 7. & 2020 & $\begin{array}{l}\text { Mila Padliah, Heni } \\
\text { Pujiastuti }\end{array}$ & $\begin{array}{l}\text { The effect of crea- } \\
\text { tivity and learning } \\
\text { styles in mathematics } \\
\text { subjects on students' } \\
\text { mathematics } \\
\text { learning outcomes }\end{array}$ & $\begin{array}{l}\text { Delta: Scientific } \\
\text { Article of } \\
\text { Mathematics } \\
\text { Education }\end{array}$ & 0 & $\begin{array}{l}\text { Pekalongan } \\
\text { University }\end{array}$ \\
\hline 8. & 2019 & Muhammad Amin & The effect of scien- & Dirasah: Journal & 0 & STIE Mahardika \\
\hline
\end{tabular}


Momentum: Physics Education Journal, 5 (1), 2021, 14

Surya Haryandi et al

\begin{tabular}{|c|c|c|c|c|c|c|}
\hline No. & $\begin{array}{c}\text { Year of } \\
\text { Publication }\end{array}$ & Author & Title & Journal & Citation & Publisher \\
\hline & & & $\begin{array}{l}\text { tific learning app- } \\
\text { roach on students' } \\
\text { learning creativity }\end{array}$ & $\begin{array}{l}\text { of Islamic Edu- } \\
\text { cation Science } \\
\text { and Manage- } \\
\text { ment Studies }\end{array}$ & & \\
\hline 9. & 2019 & $\begin{array}{l}\text { Yopita Sari, Badru } \\
\text { Zaman, Ocih Setiasih }\end{array}$ & $\begin{array}{l}\text { The profile of teacher } \\
\text { creativity in develop- } \\
\text { ing learning media }\end{array}$ & Edukid & 0 & $\begin{array}{l}\text { Indonesia } \\
\text { University of } \\
\text { Education (UPI) }\end{array}$ \\
\hline 10. & 2020 & $\begin{array}{l}\text { Poetri Lestari } \\
\text { Lokapitasari } \\
\text { Belluano, } \\
\text { Purnawansyah } \\
\text { Purnawansyah, } \\
\text { Benny Leonard } \\
\text { Enrico Panggabean, } \\
\text { Herman Herman }\end{array}$ & $\begin{array}{l}\text { Information system } \\
\text { program for } \\
\text { students' creativity } \\
\text { based on web service } \\
\text { and microservice }\end{array}$ & $\begin{array}{l}\text { ILKOM Scientific } \\
\text { Journal }\end{array}$ & 0 & $\begin{array}{l}\text { Muslim } \\
\text { University of } \\
\text { Indonesia }\end{array}$ \\
\hline
\end{tabular}

The second highest rankings of PoP sorting version for publishers on the topic of scientific creativity are shown in Table 3 . Based on Table 2, it is known that PoP ranks ten articles that are most relevant to the keywords of scientific creativity. Number 1 has the highest relevance.

Table 3. Top Two Rankings of Publishers on Scientific Creativity

\begin{tabular}{clc}
\hline No. & \multicolumn{1}{c}{ Publishers } & Number of Articles \\
\hline 1. & Ganesha University of Education & 2 \\
2. & Center for Journal Management and Publication, Lambung Mangkurat University & 2 \\
\hline
\end{tabular}

VOSviewer can provide bibliometric analysis mapping with three different visualizations (Hamidah et al., 2020). The visualization of the network can be seen in Figure 2, whereas the visualization of the overlay is displayed in Figure 3 , and the visualization of the density is represented in Figure 4.

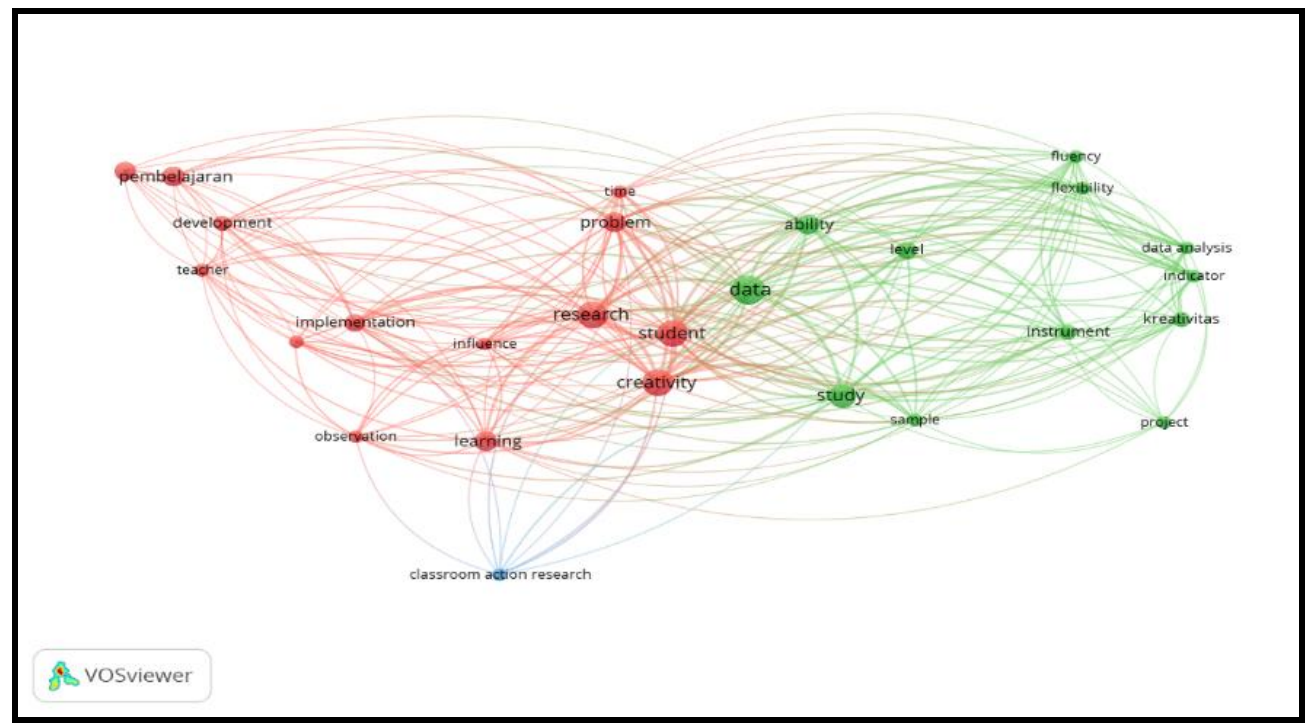

Figure 2. The Visualization of the Network in Crossref Database

Based on Figure 2, three clusters can be identified, which are characterized by different colours, specifically red, green, and blue. Each colour indicates the division of the zone and the number of keywords associated with each other. In Figure 2, it can be concluded that there are three zone divisions, specifically the red zone on the left, the green zone on the right, and the blue zone at the bottom. Keywords that are related to each other will be marked with the same colour. The red colour has the most relationship; specifically, there are 14 items, followed by 12 items in green and one item in blue. 


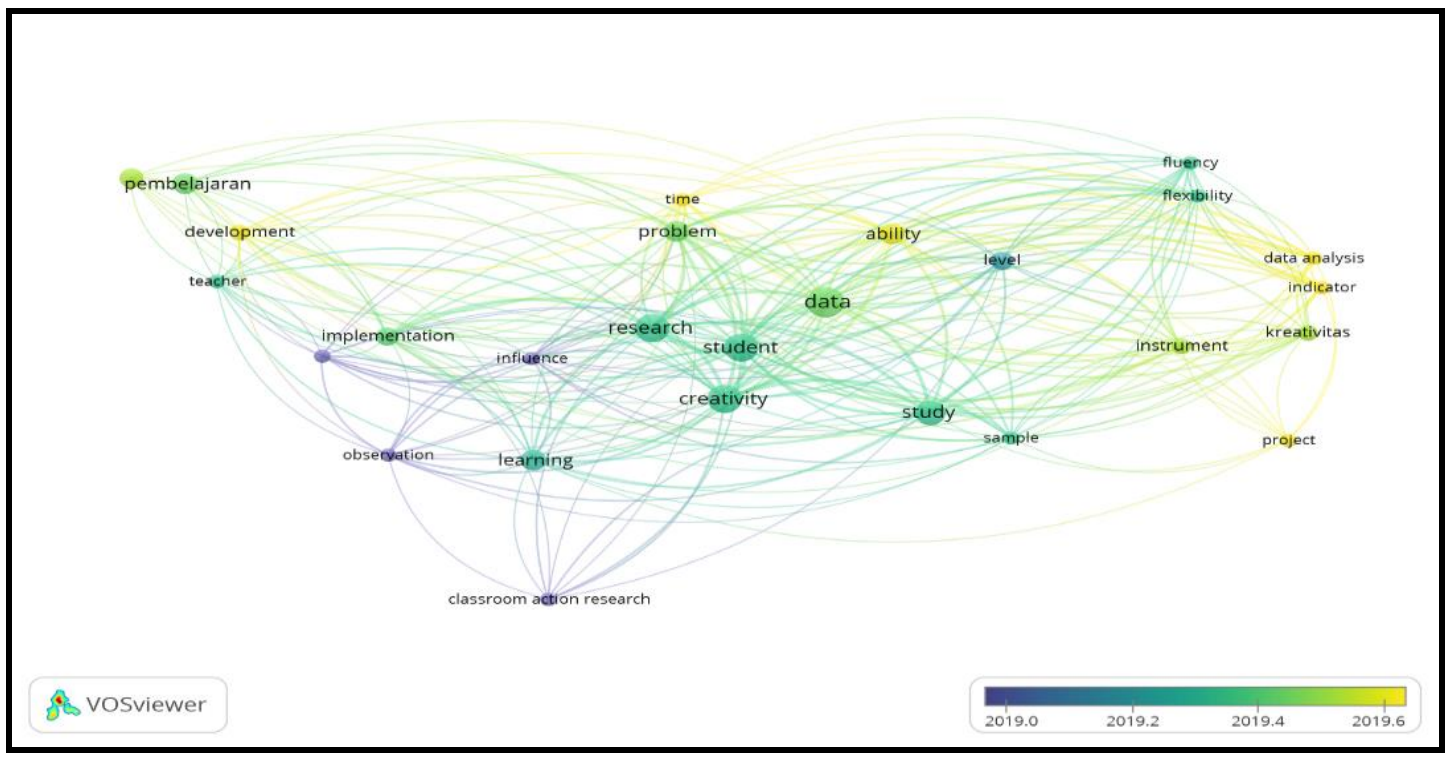

Figure 3. The Visualization of the Crossref Database Overlay

Figure 3 illustrates the publication update rate of keywords which are characterized by shades of blue and yellow. If it is closer to yellow, it means that the publication is getting newer and if it is closer to blue, it means that the publication is even earlier. In Figure 3, it can be concluded that the keywords time, ability, and project are the keywords used by other authors in their latest published articles.

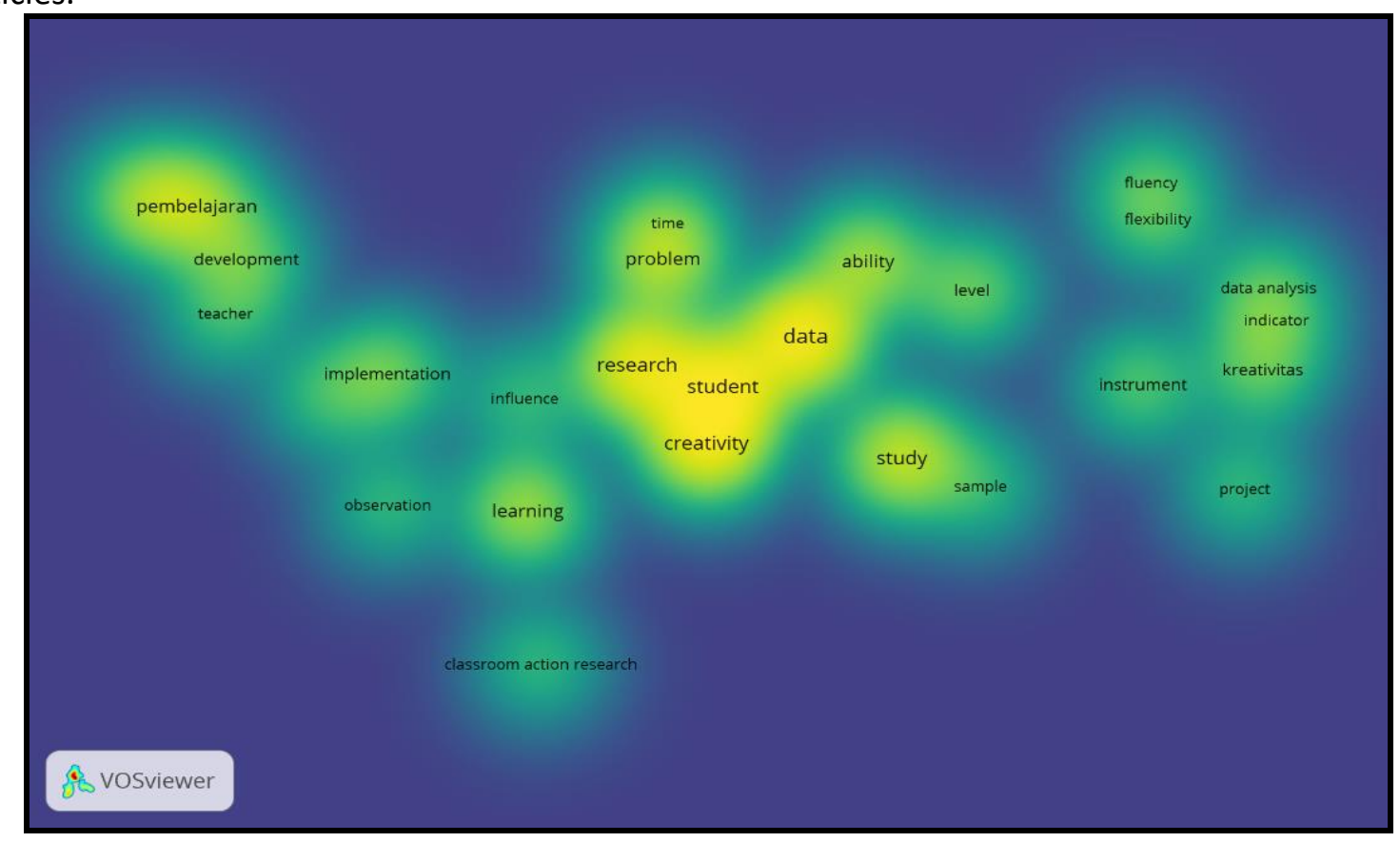

Figure 4. The Visualization of the Density of the Crossref Database

Based on Figure 4, it can be identified the density of the relationship between keywords. The tighter the relationship, the yellow pattern will be formed covering some areas where there is a relationship between the keywords of the scientific creativity variable. In Figure 4 it can be concluded that the keywords research, student, data, creativity, and ability are the most closely related keywords and are relatively often used by other authors who examine the variables of scientific creativity.

This visualization was obtained through the help of VOSviewer software by extracting as many as 28 predetermined articles based on the titles, keywords, and article abstracts. The minimum number of events was set to three. There were 27 items found which fulfilled the criteria of about 32 
items. Each item represents a keyword and is indicated by colored dots. Based on Figure 2, there are three groups/clusters which can be identified and are characterized by different colors: red, green, and blue. Each cluster shows the development of scientific creativity research in education, which can further be observed in Table 4.

Table 4. The Research Development of Each Cluster

\begin{tabular}{|c|c|c|c|}
\hline No. & Cluster & Number of Item(s) & Research Keywords \\
\hline 1. & Red cluster & 14 & $\begin{array}{l}\text { creativity (12), development (4), guru (6), implementation (5), } \\
\text { influence (3), learning (7), observation (3), pembelajaran (7), } \\
\text { pengaruh (3), problem (7), research (12), student (12), teacher (3), } \\
\text { time (3) }\end{array}$ \\
\hline 2. & Green cluster & 12 & $\begin{array}{l}\text { ability (7), data (14), data analysis (3), flexibility (3), fluency (3), } \\
\text { indicator (3), instrument (4), kreativitas (4), level (5), project (3), } \\
\text { sample (3), study (9) }\end{array}$ \\
\hline 3. & Blue cluster & 1 & clasroom action research (3) \\
\hline
\end{tabular}

Author and co-author relationships

The visualization of the author's analysis, co-author relationships and collaboration patterns between authors can be observed in Figure 5. It shows that the 27 groups/clusters can be identified and are characterized by various colors.

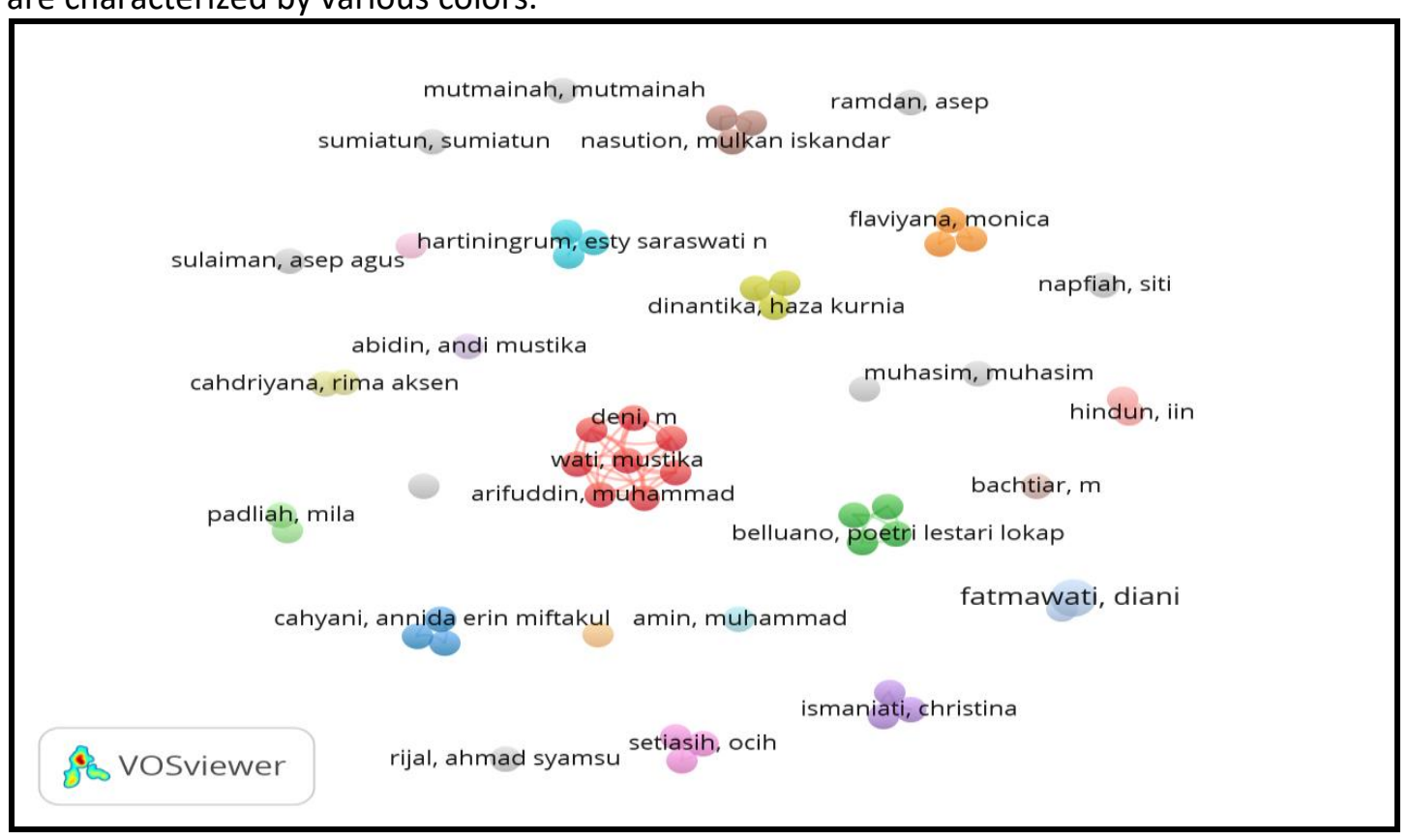

Figure 5. The Visualization of the Analysis of Author Relationships and Collaboration Patterns Between Authors

Referring to the Figure 5, quite a number of writers who do not have relationships with other authors and have not collaborated exist. There is one cluster which has the strongest collaboration pattern, namely the red cluster. The author's collaboration pattern on the red cluster is shown in detail in Figure 6.

In Figure 6, it can be seen that all the authors are interconnected to one another. If examined further, it can be seen that the relationship between all these authors belongs from the same institution, namely Lambung Mangkurat University. Drawing from these results, it can be said that the strongest collaborative relationship revolving the keyword for scientific creativity was done by authors from the institution of Lambung Mangkurat University. Unfortunately, the collaboration between authors is still within the scope of one institution, as there is no collaboration between other institutions. Analysis of the novelty of writing in the form of a time stretch is visualized in Figure 7. 


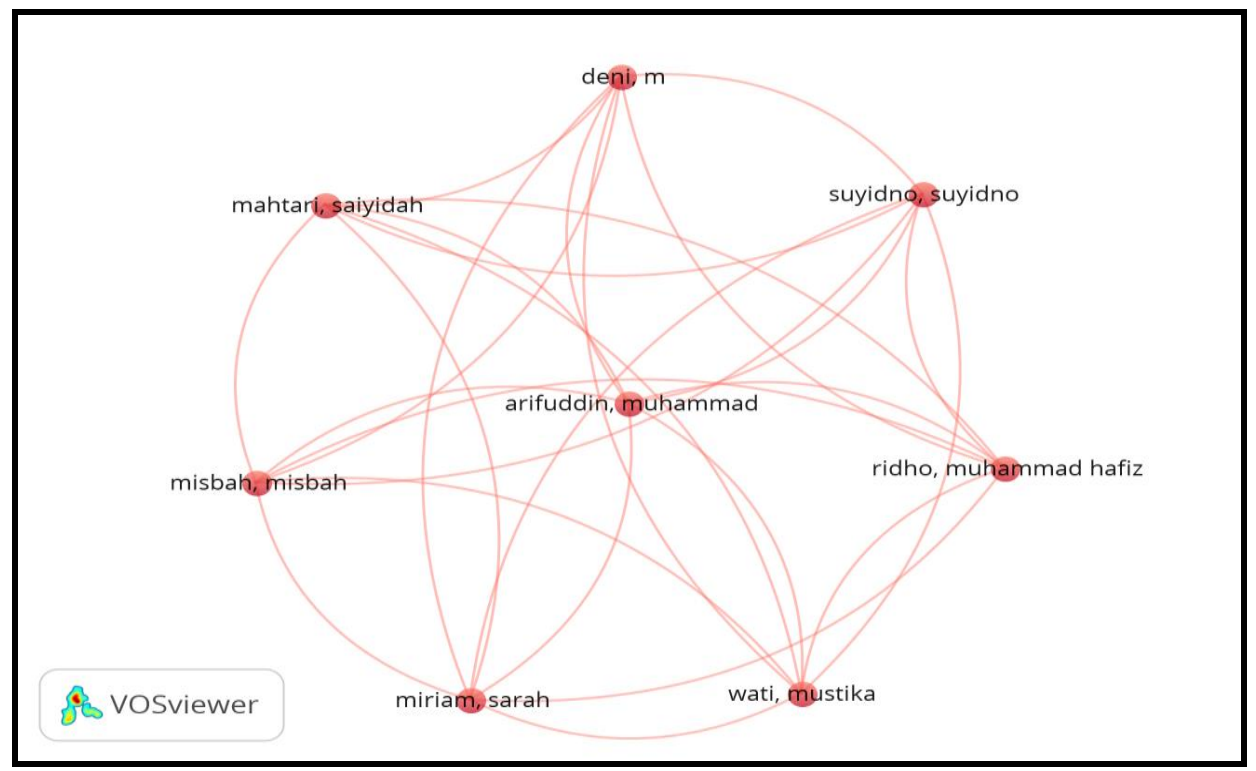

Figure 6. The Visualization of the Analysis of the Strongest Collaboration Patterns between Authors, namely in the Red Cluster

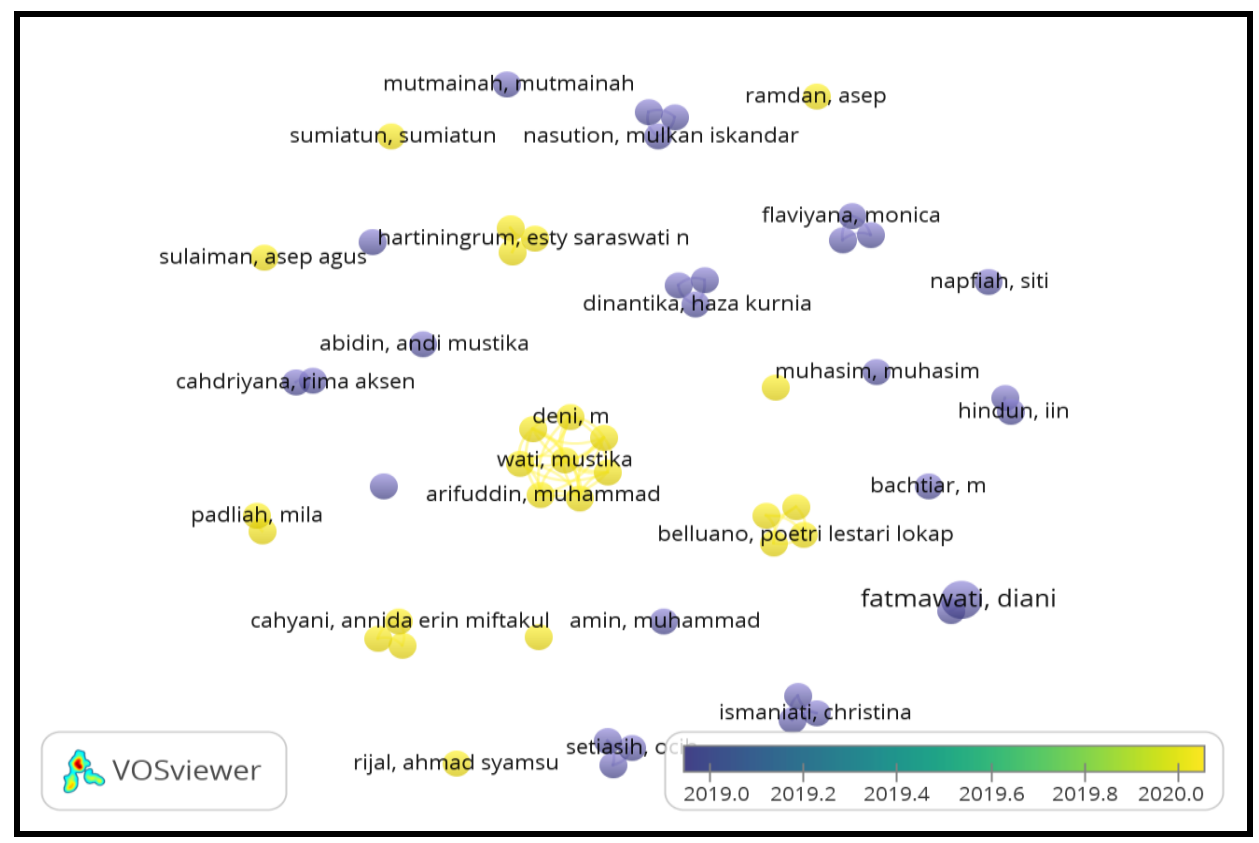

Figure 7. The Visualization of the Overlay on Authors and Collaboration Patterns between Authors on the Crossref Database

Figure 7 illustrates that the keyword for scientific creativity has only recently been researched by the yellow patterns and shapes, such as one of the studies by Sumiatun. Similar to Figure 3 , if it is getting closer to yellow, it means that the publication is getting newer and if it is getting closer to blue, it means that the publication is even earlier. The other colors do not justify that other research was held too long ago. The yellow color indicates that the research was published the same year that this journal article was written.

The novelties of this research are: (1) the successful discovery of research on scientific creativity in physics education on the Crossref database which was not available in the last 1 year; (2) the successful discovery of the collaborative relationship pattern of researchers from Indonesia who examined scientific creativity in the field of education in the last one year, previously no research revealed the pattern of the collaborative relationship; (3) based on data collected from the Google Scholar and Crossref databases, no research had been found that examines the bibliometric analysis 
of scientific creativity in the field of education in Indonesia in the last 10 years. Therefore, this research is the first research in the previous 10 years to analyze scientific creativity using bibliometric analysis. The number of citations in the keywords used is considered to be of less contribution. Nevertheless, this does not guarantee that research with the keyword 'scientific creativity' does not attract the interest of other researchers. In fact, this is due to the fact that the search year span, which is one year (2019-2020), that is set is still too short. The positive aspect which should be highlighted in this research is how high the contribution of scientific creativity in education was in the past year. The keywords used in the Indonesian language aim at mapping the extent to which these keywords are written in Indonesian language articles, which are surely published by journal articles throughout Indonesia.

An analysis was also carried out on the publisher which contributed the most journal articles in the past year. Out of the 28 published articles, two were published by the Ganesha University of Education and the two other articles were published by the Center for Journal Management and Publication, Lambung Mangkurat University. Other publishers have an average of only one article published on this keyword. This shows that the two publishers are active in publishing articles related to scientific creativity.

The network analysis carried out based on the emergence of keyword pairs explained that each cluster with the same color has keywords which are closely related to each other than other color clusters (Liu et al., 2015). The analysis of collaboration patterns between authors is also a common analytical technique used in bibliometric research to determine the similarities of certain research fields (Hudha et al., 2020). In general, the data obtained can provide an overview of the trends in scientific creativity research in the field of education for the last 10 years. This research implies that it can become a reference material for other researchers who want to examine more deeply the variable of scientific creativity and its relationship with different variables, both in the scope of secondary education and higher education. The weakness of this research is that the span of the article search years was less than the last 5 years and used Indonesian keywords.

\section{Conclusion}

Based on the results of the bibliometric analysis, it can be concluded that articles with the keyword 'scientific creativity' published in the 2019-2020 period have not been cited. The collaborative patterns of writers between institutions are still not visible. The gaps in this study indicate the direction of future projections, that scientific creativity in education is a critical subject to be studied collaboratively, not only between national institutions, but also internationally. Some suggestions that the researchers give for the next research are using keywords in English, increasing the list of article search years, for example, the last 5 years, and using other databases such as Google Scholar, Scopus, Microsoft Academic, etc. Additionally, bibliometric analysis can develop keywords used in sorting a topic such as by affiliation, city, and country, which would result in more comprehensive data (Hudha et al., 2020).

\section{References}

Akcanca, N., \& Ozsevgec, L. C. (2018). Effect of activities prepared by different teaching techniques on scientific creativity levels of prospective pre-school teachers. European Journal of Educational Research, 7(1), 71-86. https://doi.org/10.12973/eu-jer.7.1.71

Astutik, S., \& Prahani, B. K. (2018). The practicality and effectiveness of Collaborative Creativity Learning $(\mathrm{CCL})$ model by using PhET simulation to increase students' scientific creativity. International Journal of Instruction, 11(4), 409-424. https://doi.org/10.12973/iji.2018.11426a

Baneyx, A. (2008). "Publish or Perish" as citation metrics used to analyze scientific output in the humanities: International case studies in economics, geography, social sciences, philosophy, and history. Archivum Immunologiae et Therapiae Experimentalis, 56(6), 363-371.

https://doi.org/10.1007/s00005-008-0043-0 
Garza-Reyes, J. A. (2015). Lean and green - a systematic review of the state of the art literature. Journal of Cleaner Production, 102, 18-29. https://doi.org/10.1016/j.jclepro.2015.04.064

Hamidah, I., Sriyono, \& Hudha, M. N. (2020). A bibliometric analysis of covid-19 research using vosviewer. Indonesian Journal of Science and Technology, 5(2), 209-216. https://doi.org/10.17509/ijost.v5i2.24522

Hernández-Torrano, D., \& Ibrayeva, L. (2020). Creativity and education: A bibliometric mapping of the research literature (1975-2019). Thinking Skills and Creativity, 35(September 2019), 100625. https://doi.org/10.1016/j.tsc.2019.100625

Hudha, M. N., Hamidah, I., Permanasari, A., Abdullah, A. G., Rachman, I., \& Matsumoto, T. (2020). Low carbon education: A review and bibliometric analysis. European Journal of Educational Research, 9(1), 319-329. https://doi.org/10.12973/eu-jer.9.1.319

Komarudin, D. (2018). Hubungan antara kreativitas dengan prestasi belajar siswa. Psympathic : Jurnal IImiah Psikologi, 4(1), 278-288. https://doi.org/10.15575/psy.v4i1.2196

Lau, J. Y. F. (2011). An introduction to critical thinking and creativity: Think more, think better. John Wiley \& Sons.

Liu, Z., Yin, Y., Liu, W., \& Dunford, M. (2015). Visualizing the intellectual structure and evolution of innovation systems research: A bibliometric analysis. Scientometrics, 103(1), 135-158. https://doi.org/10.1007/s11192-014-1517-y

Ozdemir, G., \& Dikici, A. (2016). Relationships between scientific process skills and scientific creativity: Mediating role of nature of science knowledge. Journal of Education in Science, Environment and Health, 3(1), 52-52. https://doi.org/10.21891/jeseh.275696

Patmalasari, D., Nur Afifah, D. S., \& Resbiantoro, G. (2017). Karakteristik tingkat kreativitas siswa yang memiliki disposisi matematis tinggi dalam menyelesaikan soal matematika. JIPM (Jurnal IImiah Pendidikan Matematika), 6(1), 30. https://doi.org/10.25273/jipm.v6i1.1509

Ramadhani, I., \& Sirait, M. (2015). Efek model pembelajaran berbasis proyek dengan strategi think talk write dan kreativitas ilmiah terhadap hasil belajar kognitif tingkat tinggi siswa SMA pada pelajaran fisika. Jurnal Pendidikan Fisika, 4(1), 17. https://doi.org/10.22611/jpf.v4i1.2564

Rodrigues, M., \& Franco, M. (2020). Networks and performance of creative cities: A bibliometric analysis. City, Culture and Society, 20(October 2019), 100326. https://doi.org/10.1016/j.ccs.2019.100326

Rosa, M. S. C., Almeida, M. R. de, \& González, M. O. A. (2019). Business games and creativity: a bibliometric study and research themes. Product Management \& Development, 17(1), 31-43. https://doi.org/10.4322/pmd.2019.002

Samsudin, A., Setyadin, A. H., Suhendi, E., Chandra, D. T., \& Siahaan, P. (2018). Seventh grade students' scientific creativity test: A preliminary-study on earth science context. IOP Conference Series: Materials Science and Engineering, 288(1), 012012. https://doi.org/10.1088/1757899X/288/1/012012

Setyaningsih, I., Indarti, N., \& Jie, F. (2018). Bibliometric analysis of the term "green manufacturing." International Journal of Management Concepts and Philosophy, 11(3), 315. https://doi.org/10.1504/ijmcp.2018.093500

Suyidno, S., Nur, M., \& Yuanita, L. (2016). Developing worksheets based on scientific creativity in fundamental physics course. The 2nd International on Science Education (ISSE), 442-449.

Suyidno, S., Susilowati, E., Arifuddin, M., Misbah, M., Sunarti, T., \& Dwikoranto, D. (2019). Increasing students' responsibility and scientific creativity through creative responsibility based learning. Jurnal Penelitian Fisika Dan Aplikasinya (JPFA), 9(2), 178. https://doi.org/10.26740/jpfa.v9n2.p147-157

van Eck, N. J., \& Waltman, L. (2010). Software survey: VOSviewer, a computer program for bibliometric mapping. Scientometrics, 84(2), 523-538. https://doi.org/10.1007/s11192-009- 


\section{6-3}

Wahyudi, W., Verawati, N. N. S. P., Ayub, S., \& Prayogi, S. (2019). The Effect of Scientific Creativity in Inquiry Learning to Promote Critical Thinking Ability of Prospective Teachers. International Journal of Emerging Technologies in Learning (IJET), 14(14), 122. https://doi.org/10.3991/ijet.v14i14.9532

Yang, K. K., Hong, Z. R., Lee, L., \& Lin, H. S. (2019). Exploring the significant predictors of convergent and divergent scientific creativities. Thinking Skills and Creativity, 31(January), 252-261. https://doi.org/10.1016/j.tsc.2019.01.002

Zainudin, M., \& Irhadtanto, B. (2016). Efektivitas pembelajaran laboratorium berbasis proyek (plbp) terhadap kreativitas mahasiswa. JIPM (Jurnal IImiah Pendidikan Matematika), 5(1), 33. https://doi.org/10.25273/jipm.v5i1.853 